\title{
Individualised Homeopathic Therapy in ANCA Negative Rapidly Progressive Necrotising Crescentic Glomerulonephritis with Severe Renal Insufficiency - A Case Report
}

\author{
Seema Mahesh ${ }^{1}$, Latika Jaggi², Atul Jaggi², Dionysios Tsintzas ${ }^{3}$, George Vithoulkas ${ }^{4}$ \\ 1. Centre for Classical Homeopathy, Bangalore, India \\ 2. H3 Centre for Classical Homeopathy, Nashik, India \\ 3. Orthopaedic Department, General Hospital of Agrinio, Greece \\ 4. International Academy of Classical Homeopathy, University of the Aegean, Greece
}

Corresponding Author:
George Vithoulkas
International Academy of Classical Homeopathy,
University of the Aegean, Greece
Tel.: 00302424065142
E-mail: george@vithoulkas.com

Received: January 2nd, 2019 - Accepted: March 11th, 2019

\begin{abstract}
Anti-Neutrophil Cytoplasmic Antibody (ANCA)-negative Rapidly Progressive Glomerulonephritis (RPGN) is a severe form of autoimmune renal injury with a bleak prognosis.

A 60-year-old Indian woman was treated with classical homeopathy for ANCA-negative RPGN, and after one year of treatment, serum creatinine and other parameters indicating renal injury dropped steadily despite the withdrawal of immunosuppressive drugs; renal dialysis, which was conducted twice a week initially, was made rarer and stopped after one year.

Classical homeopathy may be considered a potential therapeutic modality in severe pathologies. Controlled studies are required to establish further the extent to which classical homeopathy may relieve patients from procedures such as dialysis that cause considerable physical and economic discomfort.
\end{abstract}

Keywords: ANCA-negative, Dialysis free, Chronic renal insufficiency, Glomerulonephritis, Homeopathy

Abbreviations: RPGN: Rapidly Progressing Glomerulonephritis; GFR: Glomerular Filtration Rate; ANCA: Anti-Neutrophil Cytoplasmic Antibody; AAV: ANCA-Associated Vasculitis; BVAS: Birmingham Vasculitis Score; CGN: Crescentic Glomerulonephritis; pANCA: Peripheral ANCA; CANCA: Cytoplasmic ANCA

\section{Introduction}

Crescentic Glomerulonephritis (CGN) causes loss of renal function rapidly through cellular proliferation within Bowman's space and formation of crescents. CGN is further differentiated on the presence of glomerular deposition of immune complexes seen on immunofluorescence. However, the majority of the CGN is pauci-immune, exhibiting no such deposits. These are termed ANCA-associated vasculitis (AAV) as these exhibit renal small-vessel vasculitis [1].

ANCA-negative RPGN is a diagnostic category of AAV that has not been studied as exhaustively as the ANCApositive cases. Only $10-15 \%$ of the pauci-immune RPGN cases are ANCA-negative [2], and it affects younger people with very little extrarenal involvement when compared to the ANCA-positive. The renal damage is much higher and the prognosis poorer. Though mortality is not different from the positive cases, the dependency on dialysis is higher, and the renal improvement with immunosuppression or plasmapheresis is minimal [3, 4].

In these cases, though histologically renal damage may be extensive, the renal outcome after treatment is more significantly related to the serum creatinine at first consultation, and those with severe renal disease remained dialysis dependent [1-10]. Studies have shown renal outcome to be poor in ANCA-negative cases with very less probability for becoming dialysis-free $[4,11]$. The negative prognostic factors for the renal outcome for CGN in general are: Glomerular Filtration Rate (GFR) $<15 \mathrm{~mL} /$ min, advancing age, higher Birmingham Vasculitis Activity Score (BVAS), low hemoglobin and higher WBC count [1]. Immunosuppressive drugs such as cyclophosphamide prescribed in these cases have their risks associated 
and may be the cause for the increased mortality in older patients with ANCA-negative RPGN, due to cardiovascular diseases and infectious complications associated with immunosuppression [7].

The following case was diagnosed with ANCAnegative RPGN with severe renal insufficiency and underwent conventional treatment for 4 months with immunosuppressive drugs, dialysis, and plasmapheresis. The patient was receiving dialysis twice a week at the time of the homeopathic consultation, with high serum creatinine and low hemoglobin. The evolution of the case under homeopathic treatment is presented here. To the best of our knowledge, this is the first case report of this diagnosis under homeopathic treatment.

\section{Case Presentation}

A 60-year-old Indian woman was diagnosed with rapidly progressing necrotizing crescentic glomerulonephritis with severe renal insufficiency in March 2015 (Table 1). She presented with a serum creatinine of $4.8 \mathrm{mg} / \mathrm{dl}$, hematuria and albuminuria (GFR $9 \mathrm{~mL} / \mathrm{min} / 1.73 \mathrm{~m}^{2}$ ).On immunofluorescence testing, she was weakly positive for Anti Nuclear Antibodies but negative for both pANCA and cANCA. The lactate dehydrogenase, depicting the extent of tissue damage, was very high (404 IU/L; Normal: 103 $227 \mathrm{IU} / \mathrm{L})$. BVAS was estimated to be 14.

She underwent conventional medical treatment until July. Initially, she received glucocorticoid and cyclophosphamide (immunosuppressive drugs) which did not control the serum creatinine. She then had to undergo plasmapheresis (5 sessions) and dialysis once a week. Despite this, the serum creatinine rose again, and the dialysis was increased to twice a week. However, there was no effective control of serum creatinine.

On 2/07/2015, with dialysis twice a week and immunosuppressive drugs, the serum creatinine was 5.2 $\mathrm{mg} / \mathrm{dl}$ (normal is up to $1.4 \mathrm{mg} / \mathrm{dl}$ ), GFR was $8 \mathrm{~mL} / \mathrm{min} / 1.73$ $\mathrm{m}^{2}$, and hemoglobin was $8.7 \mathrm{~g} \%$ (with a bone marrowstimulating injection given periodically). The patient was already developing constitutional symptoms due to the immunosuppressive drugs, with weakness, loss of appetite, weight loss, pigmentation of skin and nails and shortness of breath. The BVAS (worsening) at this point worked out to be 15 .

\section{Homeopathic intervention}

The patient sought homeopathic treatment on 16/07/2015. The homeopathic case-taking involves an exhaustive

Table 1: Laboratory findings at the moment of diagnosis (09/03/2015) and medication before homeopathic therapy

\begin{tabular}{|c|c|c|c|}
\hline Test & Patient value & Normal range & $\begin{array}{l}\text { List of medications the patient was } \\
\text { on, with content }\end{array}$ \\
\hline RBC count & $2.78 \times 10^{6} /$ cumm & $3.5-5.5 \times 10^{6} / \mathrm{cmm}$ & Auxisoda (Sodium bi carbonate) \\
\hline Hemoglobin & $8.7 \mathrm{~g} \%$ & 11 to $16 \mathrm{~g} \%$ & Calcigard (Nifedipine) \\
\hline Blood urea & $134.7 \mathrm{mg} / \mathrm{dl}$ & $15-45 \mathrm{mg} / \mathrm{dl}$ & Alprax (Alprazolam) \\
\hline Serum creatinine & $4.8 \mathrm{mg} / \mathrm{dl}$ & $0.6-1.4 \mathrm{mg} / \mathrm{dl}$ & Aciloc (rantidine) \\
\hline Estimated GFR & $9 \mathrm{~mL} / \mathrm{min} / 1.73 \mathrm{~m}^{2}$ & $>60 \mathrm{~mL} / \mathrm{min} / 1.73 \mathrm{~m}^{2}$ & Ondem (Ondansteron) \\
\hline Estimated BVAS & 14 & NA & Frusenex (Furosemide) \\
\hline Serum albumin & $3.0 \mathrm{~g} / \mathrm{dl}$ & $3.2-4.6 \mathrm{~g} / \mathrm{dl}$ & Metoz (Metolazone) \\
\hline Serum globulin & $2.1 \mathrm{~g} / \mathrm{dl}$ & $2.3-3.5 \mathrm{~g} / \mathrm{dl}$ & Aldactone (Spironolactone) \\
\hline Total serum proteins & $5.1 \mathrm{~g} / \mathrm{dl}$ & $6-7.8 \mathrm{~g} / \mathrm{dl}$ & Omnacortil (Prednisolone) \\
\hline Lactose dehydrogenase & $404.4 \mathrm{IU} / \mathrm{L}$ & $103-227$ IU/L & Endoxan (Cyclophosphamide) \\
\hline Reticulocyte count & $4 \%$ & $0.2-2 \%$ & Dargen (Darbepoetin) \\
\hline Antinuclear Antibody & weakly +ve & $-v e$ & Vozuca (Voglibose) \\
\hline PANCA & $-v e$ & NA & Linid (Linezolid) \\
\hline CANCA & $-v e$ & NA & Cardivas (Carvedilol) \\
\hline Urine albumin & $2+$ & nil & Ciplox (Ciprofloxacin) \\
\hline Urine RBC & $35-40$ hpf & nil & \\
\hline Urine Protein to Creatinine Ratio & 2.64 & $<0.5$ & \\
\hline $\begin{array}{l}\text { Abdominal and pelvic } \\
\text { ultrasound scans }\end{array}$ & $\begin{array}{l}\text { Bilateral medical renal } \\
\text { disease (Grade II) }\end{array}$ & NA & \\
\hline
\end{tabular}


recording of the patient's past medical history, treatment history and also significant events that may have had a stressful effect along with the familial medical history. The intention is to arrive at the factors that have undermined the defense mechanism of the organism. In this case, the patient related that she started having problems 5 months earlier after severe stress from the illness of her mother. It began as edema, and she was diagnosed with ANCA RPGN.

In the past, she had developed a severe form of skin eruptions which were treated conventionally. She had undergone ozone therapy for arthritis of the knee a year and a half earlier. Family history revealed that her paternal grandfather and father had both died of cancer.

Homeopathic therapy was begun after considering all these factors and the individual symptomatology. The immunosuppressive drugs were stopped from the first day of homeopathic consultation, and the steroidal drugs were tapered slowly and completely stopped within one and a half months after starting homeopathic therapy.

\section{Outcome and follow-up}

The patient steadily improved in terms of general condition (energy, appetite, weight and so forth) as well as blood reports (Table 2). As a result, she was able to increase the gap between consecutive dialysis sessions slowly, and eventually stop it in August 2016. Over the 28-month follow-up period, the patient was in a generally wellpreserved condition with steady improvement in renal function.

Table 2: Evolution under homeopathic therapy

\begin{tabular}{|c|c|c|c|c|}
\hline Date & Lab reports & Symptoms & Remedy & $\begin{array}{l}\text { Changes in } \\
\text { conventional inter- } \\
\text { ventions }\end{array}$ \\
\hline $16 / 07 / 2015$ & Serum creatinine: $5.2 \mathrm{mg} / \mathrm{dl}$ & $\begin{array}{l}\text { Severe weakness } \\
\text { Lost appetite } \\
\text { Black discoloration of nails and } \\
\text { skin since starting conventional } \\
\text { treatment } \\
\text { Face edema } \\
\text { Weight loss in one year }\end{array}$ & $\begin{array}{l}\text { Carcinosinum } 30 \mathrm{C} \text {, } \\
\text { raised to } 32 \mathrm{C} \text { after } \\
\text { one week and } 33 \mathrm{C} \\
\text { after the next } 10 \\
\text { days }\end{array}$ & $\begin{array}{l}\text { Dialysis reduced } \\
\text { to once a week; } \\
\text { Withdrawal of } \\
\text { immunosuppressive } \\
\text { drugs }\end{array}$ \\
\hline $27 / 08 / 2015$ & $\begin{array}{l}\text { Serum creatinine: } 6 \mathrm{mg} / \mathrm{dl} \\
\text { (initial response to medicine } \\
\text { brought about encouraging } \\
\text { results, so the dialysis was } \\
\text { postponed a little resulting in } \\
\text { the temporary rise) } \\
\mathrm{Hb}: 11.3 \mathrm{~g} \%\end{array}$ & $\begin{array}{l}\text { Much more energy } \\
\text { Black discoloration of nails and } \\
\text { skin reduced considerably } \\
\text { Increased urine output }\end{array}$ & $\begin{array}{l}\text { Stop carcinosinum } \\
\text { and wait }\end{array}$ & $\begin{array}{l}\text { Steroids slowly } \\
\text { tapered }\end{array}$ \\
\hline $30 / 09 / 2015$ & $\begin{array}{l}\text { Serum creatinine: } 5.14 \mathrm{mg} / \mathrm{dl} \\
\text { Blood pressure: } 110 / 70 \mathrm{~mm} \mathrm{Hg}\end{array}$ & $\begin{array}{l}\text { Gained } 2 \text { kg } \\
\text { Appetite improved }\end{array}$ & Nil & $\begin{array}{l}\text { Withdrawal of } \\
\text { antihypertensives }\end{array}$ \\
\hline $25 / 11 / 2015$ & Serum creatinine: $6.5 \mathrm{mg} / \mathrm{dl}$ & Generally very well & Nil & $\begin{array}{l}\text { Is on dialysis once in } \\
10 \text { days, advised to } \\
\text { continue the same }\end{array}$ \\
\hline $20 / 01 / 2016$ & Serum creatinine: $4.3 \mathrm{mg} / \mathrm{dl}$ & $\begin{array}{l}\text { Gained } 3.5 \mathrm{~kg} \\
\text { Improved energy and appetite } \\
\text { Eruptions appeared on the left } \\
\text { elbow (had them in the past) }\end{array}$ & Nil & $\begin{array}{l}\text { Dialysis reduced to } \\
\text { once a fortnight }\end{array}$ \\
\hline $17 / 02 / 2016$ & Serum creatinine: $5.5 \mathrm{mg} / \mathrm{dl}$ & Generally in good condition & Nil & $\begin{array}{l}\text { Dialysis reduced to } \\
\text { once a fortnight }\end{array}$ \\
\hline $17 / 03 / 2016$ & Serum creatinine: $5.6 \mathrm{mg} / \mathrm{dl}$ & $\begin{array}{l}\text { Emotionally stressed after her } \\
\text { mother died } \\
\text { Developed acute lower } \\
\text { respiratory tract infection - } \\
\text { rattling cough, dyspnea, low } \\
\text { appetite and energy }\end{array}$ & $\begin{array}{l}\text { Ammoniacum } \\
\text { gummi } 30 \mathrm{C}\end{array}$ & Nil \\
\hline
\end{tabular}




\begin{tabular}{|c|c|c|c|c|}
\hline Date & Lab reports & Symptoms & Remedy & $\begin{array}{l}\text { Changes in } \\
\text { conventional inter- } \\
\text { ventions }\end{array}$ \\
\hline $13 / 04 / 2016$ & Serum creatinine: $4.7 \mathrm{mg} / \mathrm{dl}$ & Generally very well & Nil & $\mathrm{Nil}$ \\
\hline $04 / 05 / 2016$ & $\begin{array}{l}\text { Serum creatinine: } 5.6 \mathrm{mg} / \mathrm{dl} \\
\text { Blood urea: } 95.5 \mathrm{mg} / \mathrm{dl}\end{array}$ & $\begin{array}{l}\text { Low appetite for } 15 \text { days with } \\
\text { nausea } \\
\text { Weight reduced } 1 \mathrm{~kg} \\
\text { Leg cramps } \\
\text { Disturbed sleep } \\
\text { Occasional loose stools }\end{array}$ & Sulphur $200 \mathrm{C}$ & Nil \\
\hline $01 / 06 / 2016$ & Serum creatinine: $4.9 \mathrm{mg} / \mathrm{dl}$ & $\begin{array}{l}\text { Nausea absence } \\
\text { Increased appetite } \\
\text { More energy } \\
\text { No loose stools } \\
\text { No leg cramps } \\
\text { Better sleep }\end{array}$ & Nil & Nil \\
\hline $29 / 06 / 2016$ & Serum creatinine: $4.7 \mathrm{mg} / \mathrm{dl}$ & $\begin{array}{l}\text { Generally very well } \\
\text { Increased skin eruptions on the } \\
\text { elbow } \\
\text { Dry skin, itching eczema on the } \\
\text { right hand and knuckles }\end{array}$ & Nil & $\begin{array}{l}\text { Increased gap } \\
\text { between dialysis }\end{array}$ \\
\hline $\begin{array}{l}11 / 08 / 2016 \\
\text { (one year } \\
\text { after } \\
\text { beginning } \\
\text { homeopathy) }\end{array}$ & $\begin{array}{l}\text { Serum creatinine: } 4.5 \mathrm{mg} / \mathrm{dl} \\
\text { RBC: } 3.72 \times 10^{6} / \mathrm{cmm} \\
\mathrm{Hb}: 11.6 \mathrm{~g} \%\end{array}$ & $\begin{array}{l}\text { Weight increased by } 2 \mathrm{~kg} \\
\text { Improved energy and appetite } \\
\text { Eruptions increasing }\end{array}$ & Nil & $\mathrm{Nil}$ \\
\hline $29 / 09 / 2016$ & Serum creatinine: $3.7 \mathrm{mg} / \mathrm{dl}$ & $\begin{array}{l}\text { Had fever for } 2 \text { days } \\
\text { Improved energy } \\
\text { Feels like before the onset of } \\
\text { the disease } \\
\text { Skin eruptions still increasing on } \\
\text { the knees }\end{array}$ & Nil & $\begin{array}{l}\text { Last dialysis on } \\
24 / 08 / 2016 \text { - AV } \\
\text { fistula closed by } \\
\text { accident and the } \\
\text { patient did not return } \\
\text { voluntarily for dialysis } \\
\text { Took two paracetamol } \\
\text { tablets in between for } \\
\text { a mild fever }\end{array}$ \\
\hline
\end{tabular}

\begin{tabular}{|c|c|c|c|c|}
\hline $01 / 12 / 2016$ & $\begin{array}{l}\text { Serum creatinine: } 3.4 \mathrm{mg} / \mathrm{dl} \\
\mathrm{Hb}: 11.2 \mathrm{G} \% \\
\mathrm{RBC}: 3.56 \times 10^{6} / \mathrm{cmm} \\
\text { SPO2: } 97 \% \\
\text { Urine albumin ++ }\end{array}$ & $\begin{array}{l}\text { Nephrology assessment: } \\
\text { Edema - nil } \\
\text { Dyspnea - nil } \\
\text { Appetite - good } \\
\text { Urine - normal } \\
\text { CVS/CNS - normal } \\
\text { Blood pressure: } 130 / 80 \mathrm{~mm} \mathrm{Hg}\end{array}$ & Nil & $\begin{array}{l}\text { No dialysis for } 3 \\
\text { months }\end{array}$ \\
\hline $16 / 05 / 2017$ & $\begin{array}{l}\text { Serum creatinine: } 3 \mathrm{mg} / \mathrm{dl} \\
\mathrm{Hb}: 10.9 \mathrm{~g} \% \\
\text { Urine albumin: traces }\end{array}$ & $\begin{array}{l}\text { Generally very well } \\
\text { Skin eruptions are reducing }\end{array}$ & Nil & Nil \\
\hline 03/11/2017 & Serum creatinine: $2.7 \mathrm{mg} / \mathrm{dl}$ & Reduced skin eruptions & Nil & $\begin{array}{l}\text { Nil } \\
\text { No dialysis since } 14.5 \\
\text { months }\end{array}$ \\
\hline
\end{tabular}


The latest serum creatinine is $2.6 \mathrm{mg} / \mathrm{dl}$, hemoglobin is $11.9 \mathrm{~g} \%$, and the BVAS is estimated to be 4 and GFR is $19 \mathrm{~mL} / \mathrm{min} / 1.73 \mathrm{~m}^{2}$. The patient continues homeopathic therapy.

\section{Discussion}

Renal dialysis is a considerably stressful procedure for patients, and it can be economically draining as well. It also carries the risk of various infections and iatrogenic complications [12, 13]. In severely affected RPGN, there is little else that can help alleviate the disease (except renal transplant), and the patient needs to undergo this cumbersome procedure regularly [6]. In the case of this 60-year-old patient, renal dialysis was altogether dispensed with, and the renal function was also restored to a certain extent in 28 months of follow-up.

The homeopathic perspective of a disease is holistic. It considers the whole process of inflammatory changes that have occurred from birth to the given point in time. 'The Continuum of a Unified Theory of Diseases' propounds the idea that all the pathological processes in a person from the time of birth to death form a continuum and are not incidental [14]. Initially, when the immune system is in a good state, it successfully mounts acute inflammation and drives away the pathogenic stimulus. When continuously thwarted through anti-inflammatory drugs or other substances that hinder inflammation, it loses the ability to react through strong inflammation and enters a state of chronic low-grade inflammation, eventually turning on the chronic disease that one is predisposed to. At such a stage, homeopathic therapy has been shown to reverse this situation, and as the chronic problem becomes simplified, the person begins to have acute diseases again [15-17]. Also, if any superficial inflammatory disease was suppressed through medication, at this point it returns, and such a return is a further confirmation of the immune system reverting to its previous state.

In this case, the patient had an episode of respiratory infection as the renal function started to improve, which was also treated by homeopathy. Further, she developed skin eruptions again, similar to what she had many years ago and was aggressively treated then. This time, the condition responded very well to the ongoing homeopathic treatment, and the eruptions have become less aggressive.

This rule of return of old suppressed conditions and onset of acute diseases as the chronic one becomes better is used as a guide by the homeopathic therapist to decide the direction the case is taking and to understand

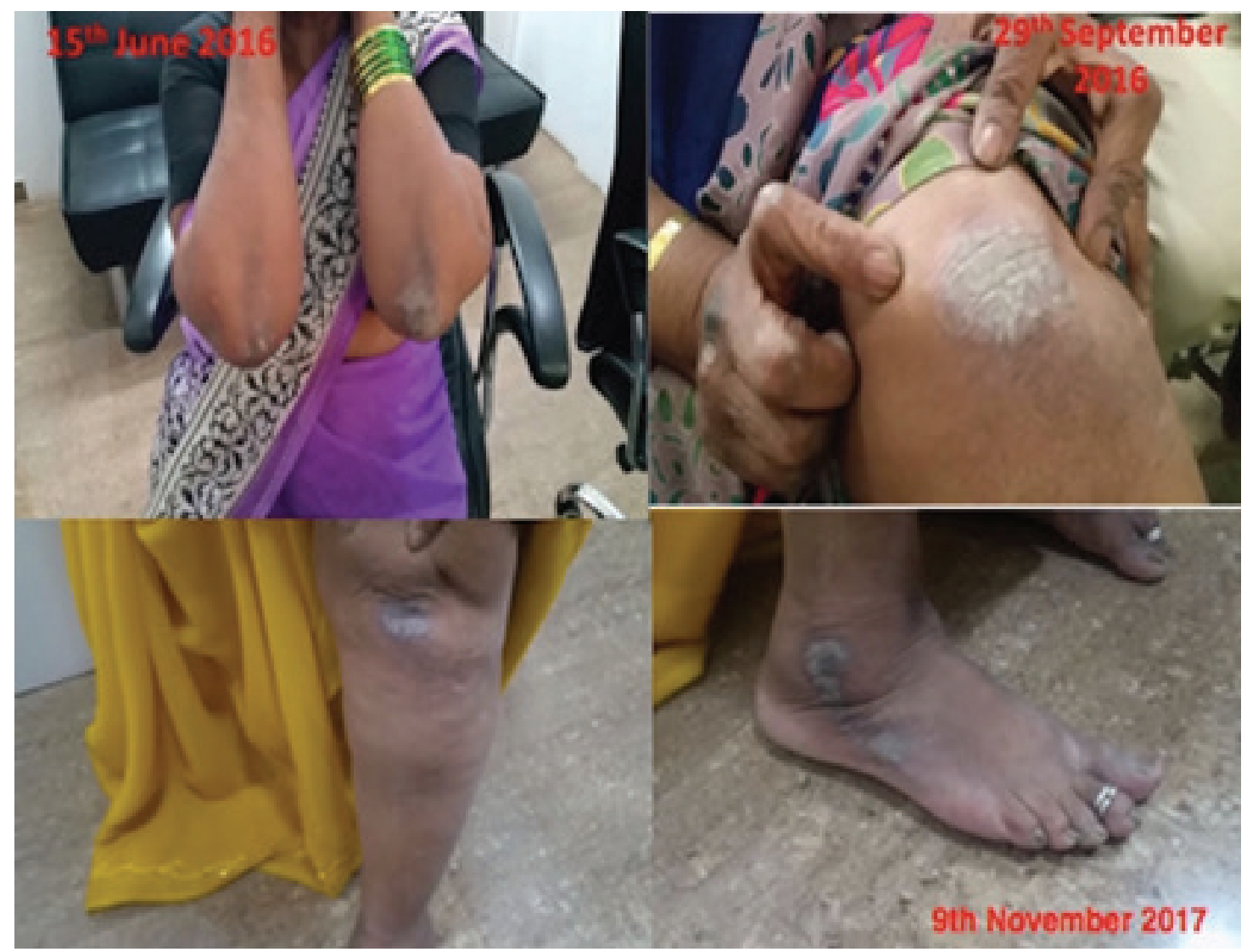

Figure 1: Onset and progress of the skin lesions during homeopathic therapy 
the prognosis in a given case $[18,19]$. As it happens, in this case, the outcome was very good.

The effect of homeopathic therapy is evident also in terms of pathology as is evidenced by the improvement of GFR from $8 \mathrm{~mL} / \mathrm{min} / 1.73 \mathrm{~m}^{2}$ to $19 \mathrm{~mL} / \mathrm{min} / 1.73 \mathrm{~m}^{2}$ and BVAS from 15 to 4.

The immunosuppressive drugs were stopped early on during homeopathic therapy resulting in elevated serum creatinine indicating the effect of immunosuppression withdrawal. However, this gradually responded to homeopathic therapy, and the patient was able to stop dialysis. The patient has remained free of drugs and dialysis for 20 months now, with steady improvement in renal function. This is reasonable grounds to plan more extensive controlled studies in the future.

Severe disorders and autoimmune conditions have been shown to respond to homeopathic therapy before now, and this case also indicates a possibility for this therapy [20-24]. There is a selection bias in this case as the patient opted for the treatment and the response was good. A controlled study will help establish the exact extent to which homeopathy may be of help and in this kind of cases.

\section{Conclusions}

Even this rare case report of ANCA-negative RPGN showed a positive response to individualized homeopathic therapy while having poor prognosis conventionally. This suggests that RPGN may be amenable to individualized therapy in the early stages. Further, more extensive studies may establish the extent to which homeopathy may be useful in such conditions.

\section{Highlights}

- ANCA-negative RPGN is challenging to treat even with immunosuppressive drugs and dialysis.

- Further proof for the questionable utility of plasmapheresis in the case of ANCAnegative RPGN.

- Classical individualized homeopathic therapy holds some promise in this pathology and needs to be investigated further.

- The phenomena of return of acute inflammatory states along with improvement in chronic inflammatory diseases are worth investigating to throw light on the immunological changes involved.

\section{Conflict of Interest}

The authors confirm that there are no conflicts of interest.

\section{References}

1. Moroni G, Ponticelli C. Rapidly progressive crescentic glomerulonephritis: Early treatment is a must. Autoimmunity Reviews. 2014; 13(7):723-729.

2. Peschel A, Basu N, Benharkou A, Brandes R, Brown M, Dieckmann $\mathrm{R}$, et al. Autoantibodies to hLAMP-2 in ANCA-negative pauciimmune focal necrotizing GN. J Am Soc Nephrol. 2013; 25:455-63.

3. Glockner W, Sieberth H, Wichmann H, Backes E, Bambauer R, Boesken W, Bohle A, Daul A, Graben N, Keller F. Plasma exchange and immunosuppression in rapidly progressive glomerulonephritis: a controlled, multi-center study. Clinical Nephrology [Internet]. 1988 [cited 2018 Mar 11];29(1):1-8.

4. Sharma A, Nada R, Naidu G, Minz R, Kohli H, Sakhuja V, Gupta K, Rathi M. Pauci-immune glomerulonephritis: does negativity of antineutrophilic cytoplasmic antibodies matters? International Journal of Rheumatic Diseases. 2015; 19(1):74-81.

5. Atkins RC, Nikolic-Paterson DJ, Song Q, Lan HY. Modulators of crescentic glomerulonephritis. J Am Soc Nephrol. 1996; 7:2271-8.

6. Chen M, Kallenberg CGM, Zhao M-H. ANCA-negative pauci-immune crescentic glomerulonephritis. Nat Rev Nephrol. 2009; 5:313-8.

7. Eisenberger U, Fakhouri F, Vanhille P, Beaufils H, Mahr A, Guillevin L, Lesavre P, NoëI L. ANCA-negative pauci-immune renal vasculitis: histology and outcome. Nephrology Dialysis Transplantation. 2005; 20(7):1392-1399.

8. Hedger N. Incidence and outcome of pauci-immune rapidly progressive glomerulonephritis in Wessex, UK: a 10-year retrospective study. Nephrol Dial Transplant. 2000; 15:1593-9.

9. Jennette JC. Rapidly progressive crescentic glomerulonephritis. Kidney Int. 2003;63:1164-77.

10. Sampathkumar K, Ramakrishnan M, Sah AK, Gowtham S, Ajeshkumar RN. ANCA negative pauci-immune glomerulonephritis with systemic involvement. Indian J Nephrol. 2010; 20:43-47.

11. Hung P, Chiu Y, Lin W, Chiang W, Chen Y, Lin S, Wu K, Tsai T. Poor Renal Outcome of Antineutrophil Cytoplasmic Antibody Negative Pauci-immune Glomerulonephritis in Taiwanese. Journal of the Formosan Medical Association. 2006; 105(10):804-812.

12. Abram HS, Moore GL, Westervelt FB. Suicidal behavior in chronic dialysis patients. Am J Psychiatry. 1971; 127:1199-204.

13. Schieppati A, Remuzzi G. Chronic renal diseases as a public health problem: epidemiology, social, and economic implications. Kidney Int. 2005; 68:S7-10.

14. Vithoulkas G, Carlino S. The "continuum" of a unified theory of diseases. Med Sci Monit. 2010; 16(2):SR7-15

15. Kivellos S, Skifti S, Vithoulkas G. EHMTI-0396. Reappearance of high fever on migraine patients, after individualized homeopathic treatment, is a valuable prognostic factor. The Journal of Headache and Pain. 2014; 15:(S1).

16. Vithoulkas G. Levels of health. Alonissos, Greece: International Academy of Classical Homeopathy; 2017.

17. Vithoulkas G, Tiller W. The science of homeopathy. Athens: International Academy of Classical Homeopathy; 2009.

18. Chabanov D, Tsintzas D, Vithoulkas G. Levels of Health Theory With the Example of a Case of Juvenile Rheumatoid Arthritis. Journal of evidencebased integrative medicine. 2018 Jun 11;23:2515690X18777995.

19. Kivellos S, Skifti S, Vithoulkas G. EHMTI-0396. Reappearance of high fever on migraine patients, after individualized homeopathic treatment, is a valuable prognostic factor. In The Journal of Headache and Pain 2014 Dec (Vol. 15, No. 1, p. M7). 
20. Mahesh S, Mallappa M, Vithoulkas G. Embryonal carcinoma with immature teratoma: A homeopathic case report. Complementary Medicine Research. 2018; 25(2).

21. Mahesh S, Mallappa M, Vithoulkas G. Gangrene: five case studies of gangrene, preventing amputation through homoeopathic therapy. Indian Journal of Research in Homoeopathy. 2015; 9:114-22.

22. Mahesh S, Mallappa M, Tsintzas D, Vithoulkas G. Homeopathic Treatment of Vitiligo: A Report of Fourteen Cases. The American Journal of Case Reports. 2017; 18:1276.
23. Mahesh S, Mahesh M, Vithoulkas G. Could Homeopathy Become An Alternative Therapy In Dengue Fever? An example Of 10 Case Studies. Journal of Medicine and Life. 2018 Jan; 11(1):75.

24. Tenzera L, Djindjic B, Mihajlovic-Elez O, Pulparampil BJ, Mahesh S, Vithoulkas G. Improvements in long standing cardiac pathologies by individualized homeopathic remedies: A case series. SAGE open Medical Case Reports. 2018 Aug;6:2050313X18792813. 